Original Research Paper

\title{
SSR Analysis of Nuclear DNA of Annual and Perennial Sunflower Species (Helianthus L.)
}

\author{
${ }^{1,4}$ N.V. Markin, ${ }^{1}$ A.V. Usatov, ${ }^{2}$ A.V. Grinko, ${ }^{1}$ K.F. Kan and ${ }^{3}$ V.A. Gavrilova

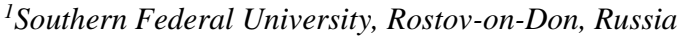 \\ ${ }^{2}$ Federal Rostov Agricultural Research Center, Rassvet, Russia \\ ${ }^{3}$ The N.I. Vavilov All Russian Institute of Plant Genetic Resources, Saint Petersburg, Russia \\ ${ }^{4}$ The Branch of the M.M. Shemyakin and Yu.A. Ovchinnikov Institute of Bioorganic Chemistry RAS, Pushchino, Russia
}

Article history

Received: 25-01-2020

Revised: 01-04-2020

Accepted: 23-04-2020

Corresponding Author:

N.V. Markin

Department of Genetics,

Southern Federal University,

Rostov-on-Don, Russia

Email: nmarkin@mail.ru

\begin{abstract}
Genotyping of 29 species of genus Helianthus L., including 5 annual and 24 perennial species from the collection of the N. I. Vavilov All-Russian Institute of Plant Genetic Resources has occurred, for this purpose were selected 52 SSR markers, with localization on all the 17 linkage groups of the sunflower genome. All the studied sunflower samples had unique SSR loci banding patterns. The mean PIC value varied was 0,72 , which indicates the high resolution of this SSR based system for sunflower nuclear genome investigations. The discriminatory power of the marker system allowed us to classify all the sunflower species and provide the molecular barcoding. The UPGMA dendrogram, reflecting the genetic differences between 29 species of the genus Helianthus L., was constructed. Allele distribution data of the studied sunflower samples is a database that can be used to determine the levels of genetic variability, provide molecular barcoding and control the genetic integrity of collection sunflower samples.
\end{abstract}

Keywords: SSR Markers, Polymorphism, UPGMA, Sunflower

\section{Introduction}

The investigations of plant genomes variability is an up today issue with both fundamental and applied interest. The application of genomic data enables the determination of the genetic diversity and relationships of various plant species, as well as the development of barcoding systems for agricultural and collection samples. To study the variability of the sunflower genome, a number of different criteria were used: morphological (Schilling and Heiser, 1981), chemical (Spring and Schilling, 1989; 1990), isoenzyme (Carrera and Poverene, 1995; Cronn et al., 1997), RFLP (Gentzbittel et al., 1994; Berry et al., 1994; Schilling, 1997), DNA sequence data (Vischi et al., 2006; Timme et al., 2007), transcriptomes (Baute et al., 2015; Smith et al., 2018), as well as variations in the number of retrotransposons copies (Mascagni et al., 2015; 2018). However, even nowadays, for the identification of annual and perennial wild-growing sunflowers species, the Heizer's classification (Heiser et al., 1969), based on visual assessment of the morphological characteristics, is still predominantly used. Nevertheless, such classification has some disadvantages and limitations, for instance, the morphological characters are not always clearly expressed at different stages. Thus the application of DNA markers revealed new possibilities for studying genetic diversity and relationships at the intraspecific and generic levels (Knapp et al., 2001). The most effective and simplest molecular methods for assessing genetic polymorphism are PCR-based techniques. Among such techniques, the Random Amplified Polymorphic DNA (RAPD) and Simple Sequence Repeats (SSR) markers are widely used, allowing rapid detection of the variability of a large number of genome loci (Sivolap and Solodenko, 1998; Sossey-Alaoui et al., 1998; 1999; Markin et al., 2016; Suresha et al., 2017; Yang et al., 2018; Uma et al., 2018). The spectra of DNA fragments, obtained as a result of their amplification, can be used as genetic markers for species identification and barcoding, as well as for determining taxonomic differences between species. The aim of the current investigation is genotyping of annual and perennial sunflower species from the collection of the N. I. Vavilov All-Russian Institute of Plant Genetic Resources (VIR) based on the polymorphism of microsatellite markers. 


\section{Materials and Methods}

The objects of the study were samples of 5 annual and 24 perennial species of sunflower from the collection of the N. I. Vavilov All-Russian Institute of Plant Genetic Resources (Table 1).
Using sunflower map from NCBI database (https://www.ncbi.nlm.nih.gov/projects/mapview/map_sear ch.cgi?taxid=4232\&query=Helianthus), we selected 52 SSR markers, with localization on all the 17 linkage groups (chromosomes) of the sunflower genome (Table 2).

Table 1: The list of sunflower samples from the VIR collection according to the Schilling and Heiser (1981) species classification

\begin{tabular}{|c|c|c|c|c|c|}
\hline$I / n$ & Species & $\begin{array}{l}\text { Chromosome } \\
\text { number, } 2 \mathrm{n}\end{array}$ & $\begin{array}{l}\text { Introduction number } \\
\text { in the VIR collection }\end{array}$ & Section & Subsectio \\
\hline & Annual & & & & \\
\hline 1. & H. annuus $\mathrm{L}$. & 34 & 598276 & Helianthi & - \\
\hline 2. & H. annuus $\mathrm{L}$. & 34 & 545522 & & \\
\hline 3. & H. annuus L. & 34 & 441098 & & \\
\hline 4. & H. annuus L. & 34 & 549513 & & \\
\hline 5. & H. annuus $\mathrm{L}$. & 34 & 506067 & & \\
\hline 6. & H. annuus $\mathrm{L}$. & 34 & 545563 & & \\
\hline 7. & H. annuus $\mathrm{L}$. & 34 & 545616 & & \\
\hline 8. & H. annuus $\mathrm{L}$. & 34 & 545736 & & \\
\hline 9. & H. annuus L. & 34 & 436863 & & \\
\hline 10. & H. annuus $\mathrm{L}$. & 34 & 545500 & & \\
\hline 11. & H. annuus $\mathrm{L}$. & 34 & 545598 & & \\
\hline 12. & $\begin{array}{l}\text { H. annuus breeding } \\
\text { form VIR } 119\end{array}$ & 34 & - & & \\
\hline 13. & H. debilis Nutt. & 34 & 560395 & & \\
\hline 14. & H. praecox Engelm. and A. Gray & 34 & 560400 & & \\
\hline 15. & H. agrophylus Torr. and A. Gray & 34 & 1000 & & \\
\hline 16. & $\begin{array}{l}\text { H. petiolaris Nutt. } \\
\text { Perennial }\end{array}$ & 34 & 503232 & & \\
\hline 17. & H. ciliaris DC. & 68,102 & - & Ciliares & Ciliares \\
\hline 18. & H. californicus DC. & 102 & 530447 & & Corona-solis \\
\hline 19. & H. decapetalus $\mathrm{L}$. & 34,68 & 440439 & & \\
\hline 20. & H. trachelifolius Mill. & 34,68 & - & & \\
\hline 21. & H. divaricatus $\mathrm{L}$. & 34 & 2099 & & \\
\hline 22. & H. eggertii Small & 102 & - & & \\
\hline 23. & H. giganteus $\mathrm{L}$. & 34 & 489235 & & \\
\hline 24. & H. grosseserratus M. Martens & 34 & 545698 & & \\
\hline 25. & H. hirsutus Raf. & 68 & 560389 & & \\
\hline 26. & H. maximiliani Schrad. & 34 & 2099 & & \\
\hline 27. & H. mollis Lam. & 34 & 2102 & & \\
\hline 28. & H. nuttallii Torr. and A. Gray & 34 & - & & \\
\hline 29. & H. salicifolius A. Dietr. & 34 & 440074 & Divaricati & \\
\hline 30 . & H. strumosus $\mathrm{L}$. & 68,102 & 440679 & & \\
\hline 31. & H. tomentosus Michx. & 102 & 2107 & & \\
\hline 32. & H. tuberosus L. & 102 & 2111 & & \\
\hline 33. & H. laevigatus Torr. and A. Gray & 68 & - & & Microcephali \\
\hline 34. & H. microcephalus Torr. and A. Gray & 34 & - & & \\
\hline 35 . & H. smithii Heiser & 68 & - & & \\
\hline 36. & $\begin{array}{l}\text { H. occidentalis Riddel subsp. } \\
\text { plantagineus (Torr. and } \\
\text { A.Gray) Heiser }\end{array}$ & 34 & 441062 & & Atrorubente \\
\hline 37. & H. rigidus Desf. & 102 & 545658 & & \\
\hline 38. & H. angustifolius $\mathrm{L}$. & 34 & 1889 & & \\
\hline 39. & H. floridanus A. Gray ex Chapm. & 34 & - & & Angustifolii \\
\hline 40. & H. simulans $\mathrm{E}$. Watson & 34 & 545659 & & \\
\hline
\end{tabular}


Table 2: SSR markers used for genotyping of sunflower

\begin{tabular}{|c|c|c|c|c|}
\hline № & SSR marker & Linkage group & Amplicon size, bp & PIC \\
\hline 1 & ORS 610 & 1 & 144 & 0,59 \\
\hline 2 & ORS 509 & & 198 & 0,56 \\
\hline 3 & ORS 552 & & $200,246,500$ & 0,68 \\
\hline 4 & ORS 1194 & 2 & $180,217,280,300,380$ & 0,82 \\
\hline 5 & ORS 1045 & & 155 & 0,83 \\
\hline 6 & ORS 653 & & 312,500 & 0,97 \\
\hline 7 & ORS 545 & 3 & 100,180 & 0,61 \\
\hline 8 & ORS 1021 & & 280,309 & 0,58 \\
\hline 9 & ORS 488 & & 179 & 0,53 \\
\hline 10 & ORS 963 & 4 & $100,300,340,600$ & 0,93 \\
\hline 11 & ORS 785 & & $100,161,200$ & 0,75 \\
\hline 12 & ORS 1217 & & 300,431 & 0,68 \\
\hline 13 & ORS 1024 & 5 & 224,250 & 0,97 \\
\hline 14 & ORS 1159 & & $200,255,400$ & 0,99 \\
\hline 15 & ORS 1120 & & $250,300,321,400,600$ & 0,95 \\
\hline 16 & ORS 650 & 6 & 100,412 & 0,99 \\
\hline 17 & ORS 381 & & $100,216,550$ & 0,96 \\
\hline 18 & ORS 1256 & & $150,180,210$ & 0,68 \\
\hline 19 & ORS 426 & 7 & 334 & 0,91 \\
\hline 20 & ORS 966 & & 372 & 0,31 \\
\hline 21 & ORS 901 & & 407 & 0,32 \\
\hline 22 & ORS 1043 & 8 & 204 & 0,86 \\
\hline 23 & ORS 243 & & 170 & 0,94 \\
\hline 24 & ORS 894 & & $150,252,350$ & 0,90 \\
\hline 25 & ORS 1265 & 9 & 222,250 & 0,63 \\
\hline 26 & ORS 887 & & 252 & 0,88 \\
\hline 27 & ORS 1220 & & 257 & 0,68 \\
\hline 28 & ORS 878 & 10 & 203,320 & 0,58 \\
\hline 29 & ORS 437 & & 342 & 0,59 \\
\hline 30 & ORS 691 & & 200,447 & 0,66 \\
\hline 31 & ORS 625 & 11 & 204,300 & 0,61 \\
\hline 32 & ORS 1214 & & 369 & 0,35 \\
\hline 33 & ORS 697 & & 238,450 & 0,66 \\
\hline 34 & ORS 502 & 12 & 120 & 0,59 \\
\hline 35 & ORS 946 & & 191 & 0,37 \\
\hline 36 & ORS 810 & & 398 & 0,97 \\
\hline 37 & ORS 707 & 13 & 100,160 & 0,52 \\
\hline 38 & ORS 1179 & & 315 & 0,99 \\
\hline 39 & ORS 799 & & 143 & 0,76 \\
\hline 40 & ORS 578 & 14 & $238,300,600,800$ & 0,98 \\
\hline 41 & ORS 398 & & 298 & 0,89 \\
\hline 42 & ORS 1086 & & 140 & 0,68 \\
\hline 43 & ORS 151 & 15 & $180,220,454$ & 0,73 \\
\hline 44 & ORS 687 & & 168 & 0,71 \\
\hline 45 & ORS 857 & & 212 & 0,68 \\
\hline 46 & ORS 899 & 16 & 323 & 0,98 \\
\hline 47 & ORS 656 & & 196 & 0,80 \\
\hline 48 & ORS 788 & & 263 & 0.94 \\
\hline 49 & ORS 996 & & $150,292,700$ & 0,79 \\
\hline 50 & ORS 297 & 17 & 225 & 0,73 \\
\hline 51 & ORS 727 & & $192,210,250,280,300$ & 0,66 \\
\hline 52 & ORS 1097 & & 130,161 & 0,68 \\
\hline
\end{tabular}

Genomic DNA was isolated from sunflower leaf tissue, with our modifications (Markin et al., 2016). PCR The PCR was carried out in $25 \mu \mathrm{L}$ reaction mixture of the following composition: $67 \mathrm{~mm}$ Tris $-\mathrm{HCl}$ buffer, $\mathrm{pH} 8.8,16 \mathrm{mM}\left(\mathrm{NH}_{4}\right)_{2} \mathrm{SO}_{4}, 2.5 \mathrm{mM} \mathrm{MgSO}_{4}, 0.1$ $\mathrm{mM}$ mercaptoethanol, $0.25 \mathrm{mM}$ of each dNTP (dATP,
dCTP, dTTP and dGTP), $400 \mathrm{nM}$ primers, 2.5 units of Taq polymerase and $15 \mathrm{ng}$ of DNA template. Amplification was performed in the thermocycler Palm Cycler (Corbett Research, Australia). Thermal regime of the reaction was chosen individually for each pair of primers on the basis of their sequences. For majority of 
reactions the optimal thermal regime was as follows: (1) denaturation at $94^{\circ} \mathrm{C}$ for $4 \mathrm{~min}$, (2) 35 cycles at the following thermal and time regime: denaturation $94^{\circ} \mathrm{C}$ $20 \mathrm{sec}$, annealing $58^{\circ} \mathrm{C}-20 \mathrm{sec}$, elongation $72^{\circ} \mathrm{C}-60$ sec (3) final elongation at $72^{\circ} \mathrm{C}$ for $10 \mathrm{~min}$. The primer sequences of the SSR markers are taken from the GenBank NCBI.

The amplicons were separated by electrophoresis in $3 \%$ agarose gel supplemented with ethidium bromide in Tris-Borate buffer. The obtained gels were analyzed with the Gel-Documenting System (GelDoc 2000, BioRad, United States). 100+ bp DNA Ladder (Evrogen, Russia) was used as a molecular weight marker. All the procedures were performed in 3-5 replicates.

For the estimation of SSR loci polymorphism, the Polymorphism Information Content (PIC) value was used. PIC $=1-\sum \mathrm{pi}^{2}$, where $\mathrm{Pi}$ is the frequency of the $\mathrm{i}$ th allele among the total number of alleles (Nei, 1973). For determination of the genetic differences in sunflower samples as well as for dendrogram construction, the TREECON program (Van de Peer and De Wachter, 1993) was applied.

\section{Results and Discussion}

According to molecular genetic analysis of 40 sunflower samples, it was determined that all 52 selected SSR markers provided well reproducible and informative data. The electrophoresis analysis of amplicons revealed 1-5 bands for each SSR marker. The variability in amplicon size was from $100 \mathrm{bp}$ to $800 \mathrm{bp}$. In total, 99 allelic variations across all studied SSR loci were defined (Table 2). While analyzing electrophoregrams the differences between samples were observed according to amplicon size, presence/absence of amplicon and multiply banding (multiple loci). As an example, Fig. 1 show the SSR profiles of annual and perennial species of sunflower using primers for one loci ORS 610.

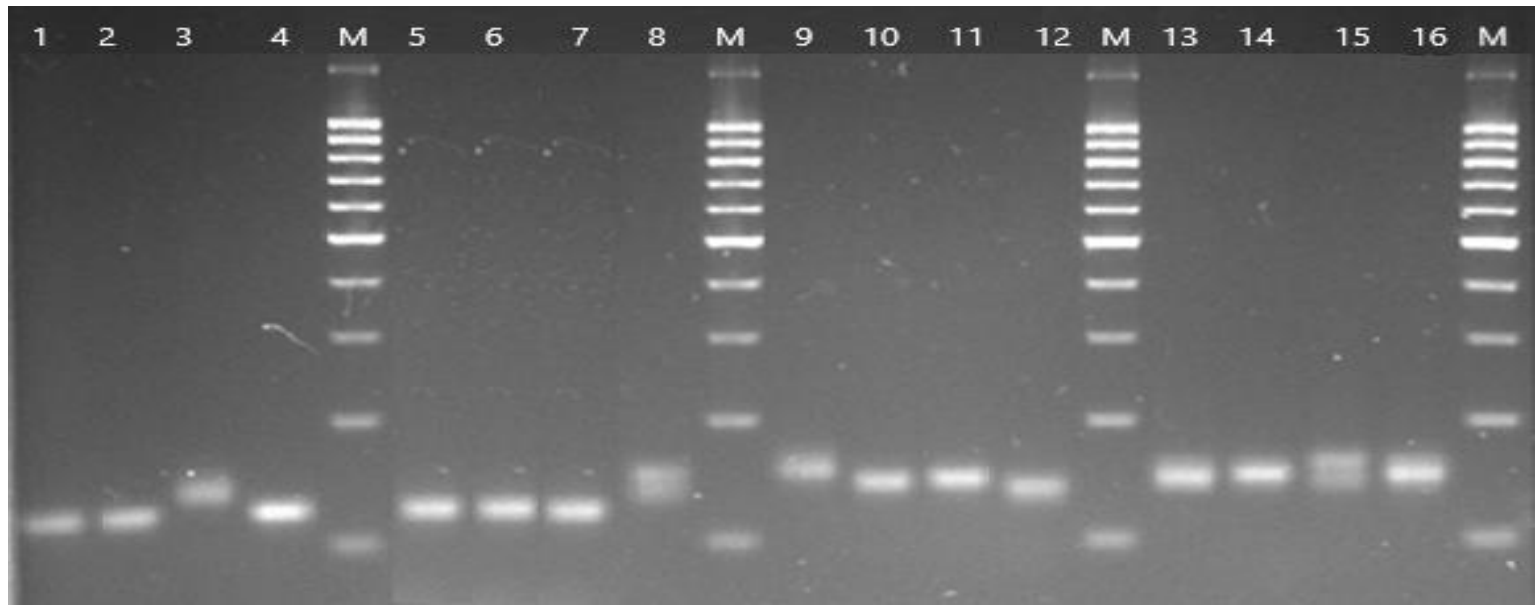

(a)

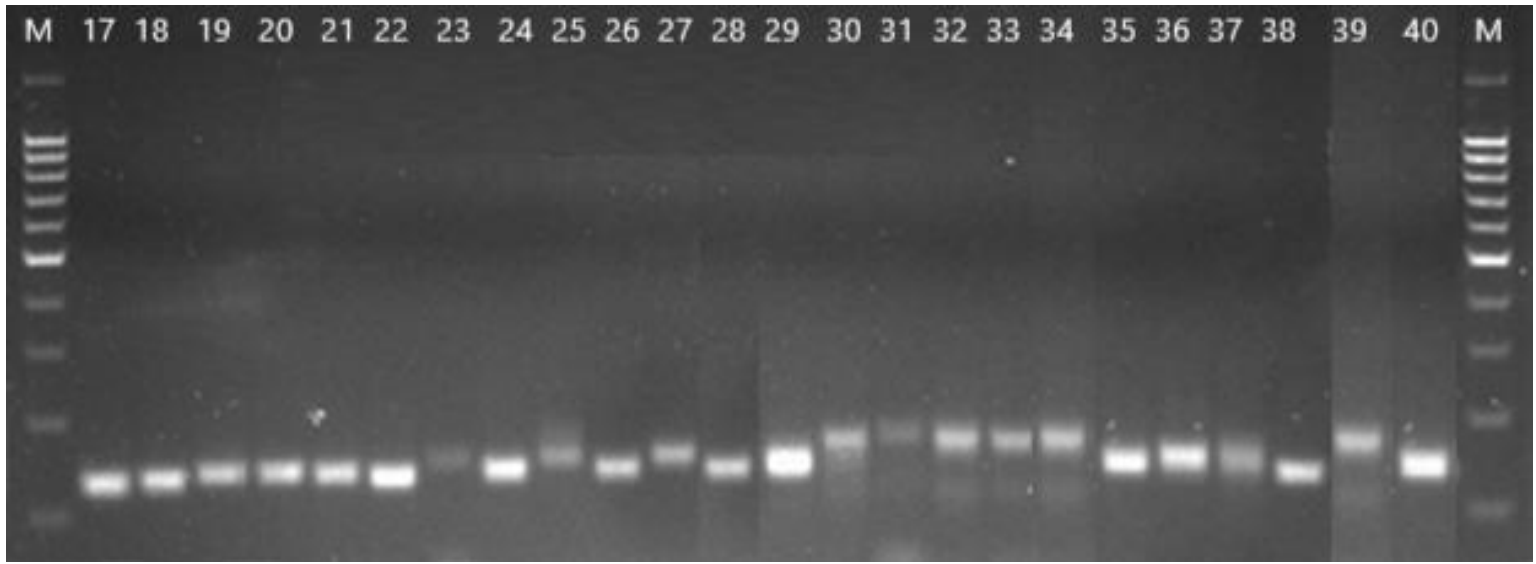

(b)

Fig. 1: SSR profiles of annual (A) and perennial (B) species of sunflower using primers for one loci ORS 610. The numbers indicated index number of species (Table 1). M - molecular weight standard (100+ bp DNA Ladder (Evrogen, Russia)) 


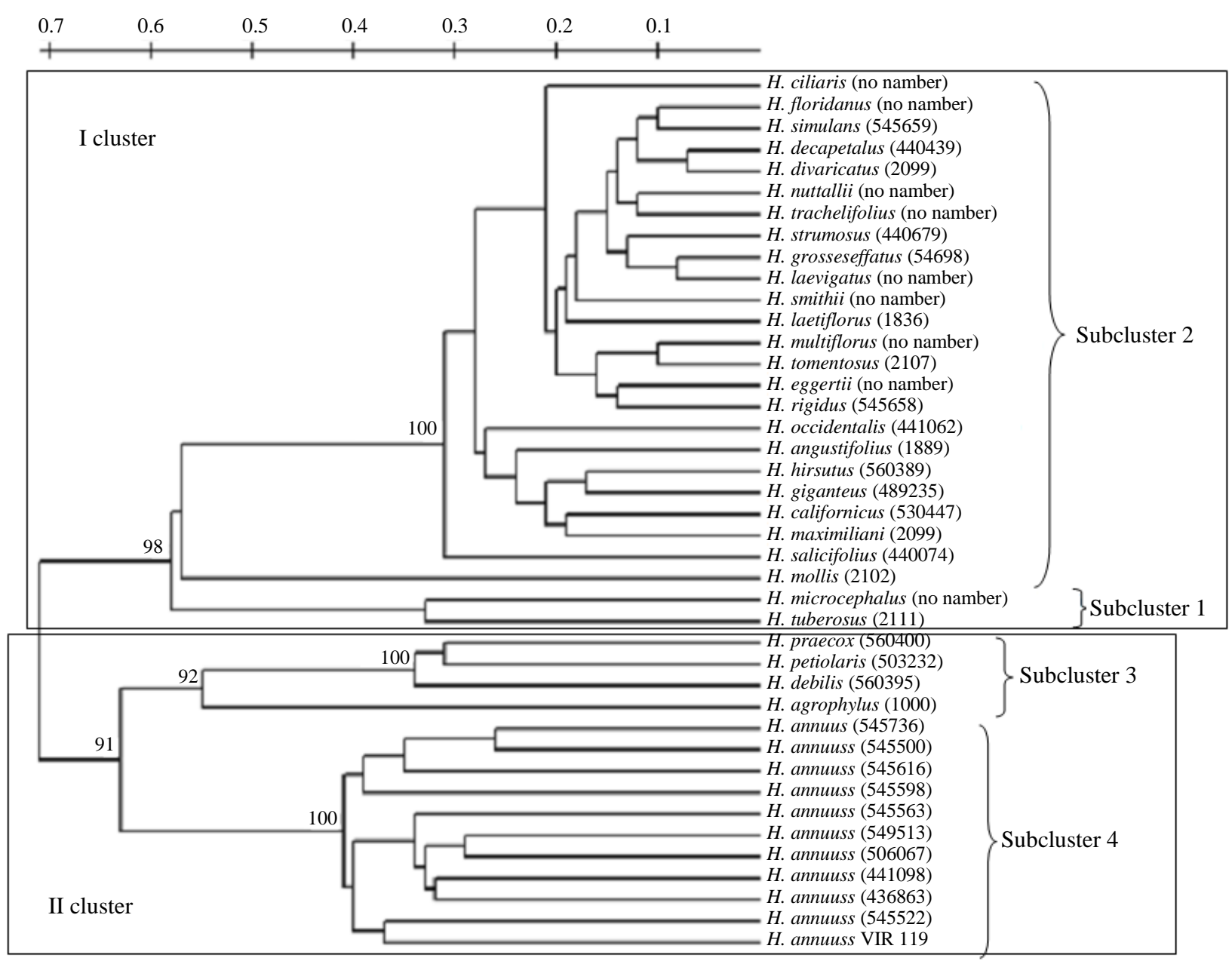

Fig. 2: UPGMA dendrogram of 42 sunflower samples based on 52 SSR loci. The introduction number of the studied samples is indicated in parentheses. The numbers indicate bootstrap values (only values greater than $90 \%$ are included

All the studied sunflower samples had unique SSR loci banding patterns. Thus the current approach indicated the effectiveness of SSR genotyping and made it possible to evaluate the genetic polymorphism of the samples. PIC values varied from 0,31 to 0,99 with the mean 0,72 , which indicates the high resolution of this SSR based system for sunflower nuclear genome investigations. Moreover, the discriminatory power of the marker system allowed us to classify all the sunflower species and provide the molecular barcoding.

Based on the data obtained, the UPGMA dendrogram, reflecting the genetic differences between 29 species of the genus Helianthus L., was constructed. In the presented dendrogram (Fig. 2), the sunflower species are combined into two main clusters with high statistical reliability - 98\% and $91 \%$ bootstrap. The first cluster includes all plants of perennial species of Helianthus L. and the second - all samples of annual sunflower. In turn, the perennial species cluster is divided into two subclusters: The first one includes only two species $(H$. tuberosus and $H$. microcephalus), while the second one - all other perennial species, in which the most divergent are $H$. mollis, $H$. salicifolius (Fig. 2). Annual species form two subclusters (subclusters 3 and 4), one is presented by $H$. annuиs species, including the VIR 119 line and another one combines all other samples of annual species: $H$. praecox, H. petiolaris, H. debilis and H. agrophylus (Fig. 2). The obtained topology of the dendrogram of perennial species differs from the taxonomy data proposed by Schilling and Heiser (1981), which was constructed according to the analysis of morphological characters. There is no relationship between clusters and subsections identified by morphological characteristics. The reticulate speciation in the Helianthus L. genus and the high level of genetic variation can explain topological incongruence between current data and the classical ideas about the systematics of perennial sunflower species (Timme et al., 2007; Mascagni et al., 2017; 2018). 
The high potential of SSR markers for investigations of plant genetic diversity was established in many studies (Ahmad et al., 2017; Wang et al., 2018; Parthiban et al., 2018). Current research of sunflower nuclear polymorphism based on analysis of52 SSR loci, allowed genotyping 29 species of the genus Helianthus L. Allele distribution data of the studied sunflower samples is a database that can be used to determine the levels of genetic variability, provide molecular barcoding, and control the genetic integrity of collection sunflower samples. Also, the dendrogram displaying the genetic relationships between the studied sunflower species was provided. Thus, the studied SSR markers are informative for assessing the level of genetic diversity of the genus Helianthus L.

\section{Acknowledgement}

This research was supported by Ministry of Education and Science of Russian Federation, project no. 6.929.2017/4.6.

Analytical work was carried out on the equipment of centers for collective use of Southern Federal University "High Technology."

\section{Author's Contributions}

All the five authors equally participated in the laboratory study, data analysis and the entire process of the article preparation.

\section{Ethics}

This article is original and contains unpublished material. The authors declare that there is no conflict of interest regarding publication of this paper. The authors declare that no ethical issues are going to arise after the work has been published.

\section{References}

Ahmad, A., J.D. Wang, Y.B. Pan, Z.H. Deng and Z.W. Chen et al., 2017. Molecular identifcation and genetic diversity analysis of Chinese sugarcane (Saccharum spp. hybrids) varieties using SSR markers. Trop Plant Biol., 10: 194-203. DOI: 10.1007/s1204 2-017-9195-6

Baute, G.J., N.C. Kane, C.J. Grassa, Z. Lai and L.H. Rieseberg, 2015. Genome scans reveal candidate domestication and improvement genes in cultivated sunflower, as well as post-domestication introgression with wild relatives. New Phytol., 206: 830-838.

DOI: 10.1111/nph.13255

Berry, S.T., R.J. Allen, S.R. Barnes and P.D. Caligari, 1994. Molecular marker analysis of Helianthus annuus L. 1. Restriction fragment length polymorphism between inbred lines of cultivated sunflower. Theor. Applied Genet., 89: 435-441. DOI: 10.1007/BF00225378.
Carrera, A. and M. Poverene, 1995. Isozyme variation in Helianthus petiolaris and sunflower, $H$. annuus. Euphytica, 81: 251-257. DOI: 10.1007/BF00025614

Cronn, R., M. Brothers, K. Klier and P.K. Bretting, 1997. Allozyme variation in domesticated annual sunflower and its wild relatives. Theor. Applied Genet., 95: 532-545. DOI: 10.1007/s001220050594

Gentzbittel, L., Y.X. Zhang, F. Vear, B. Griveau and P. Nicolas, 1994. RFLP studies on genetic relationships among inbred line of the cultivated sunflower (Helianthus annuus L.): Evidence for distinct restorer and maintainer germplasm pools. Theor. Applied Genet., 89: 419-425. DOI: 10.1007/BF00225376

Heiser, C.B., D.M. Smith, S.B. Clevenger and W.C. Martin, 1969. The North American sunflowers (Helianthus). Memoirs Torrey Botanical Club, 22: 218-218.

Knapp, S.J., S.T. Berry and L.H. Rieseberg, 2001. Genetic Mapping in Sunflowers. In: DNA-Based Markers in Plants. Advances in Cellular and Molecular Biology of Plants, Phillips, R.L. and I.K. Vasil (Eds.), Springer, Dordrecht, ISBN-13: 978-90-481-5672-6, pp: 379-403.

Markin, N.V., A.V. Usatov, V.N. Vasilenko, A.I. Klimenko and O.F. Gorbachenko et al., 2016. SSR analysis of maternal and paternal lines selected in the don region (Russia). Am. J. Agric. Biol. Sci., 11: 13-18. DOI: 10.3844/ajabssp.2016.13.18

Mascagni, F., A. Vangelisti, T. Giordani, A. Cavallini and L. Natali, 2018. Specific LTR-Retrotransposons show copy number variations between wild and cultivated sunflowers. Genes (Basel), 9: 433-433. DOI: 10.3390/genes9090433

Mascagni, F., E. Barghini, T. Giordani, L.H. Rieseberg and A. Cavallini et al., 2015. Repetitive DNA and plant domestication: Variation in copy number and proximity to genes of LTR-retrotransposons among wild and cultivated sunflower (Helianthus annuиs) genotypes. Genome Biol. Evol., 7: 3368-3382. DOI: $10.1093 / \mathrm{gbe} / \mathrm{evv} 230$

Mascagni, F., T. Giordani, M. Ceccarelli, A. Cavallini and L. Natali, 2017. Genome-wide analysis of LTRretrotransposon diversity and its impact on the evolution of the genus Helianthus (L.). BMC Genom., 18: 634-634. DOI: 10.1186/s12864-017-4050-6

Nei, M., 1973. Analysis of gene diversity in subdivided populations. Proc. National Acad. Sci. USA, 70: 3321-3323.

Parthiban, S., P. Govindaraj and S. Senthilkumar, 2018. Comparison of relative efficiency of genomic SSR and EST-SSR markers in estimating genetic diversity in sugarcane. 3 Biotech., 8: 144-144. DOI: $10.1007 / \mathrm{s} 13205-018-1172-8$

Schilling, E.E. and C.B. Heiser, 1981. Infrageneric classification of Helianthus (Compositae). Taxon, 30: 393-403. DOI: 10.2307/1220139 
Schilling, E.E., 1997. Phylogenetic analysis of Helianthus (Asteraceae) based on chloroplast DNA restriction site data. Theoretical Applied Genet., 94: 925-933. DOI: $10.1007 / \mathrm{s} 001220050497$

Sivolap, Y.M. and A.E. Solodenko, 1998. Inter- and intraspecies differentiation in the genus helianthus by RAPD analysis. Helia, 21: 9-18.

Smith, C.C.R., S. Tittes, J.P. Mendieta, E. Collier-Zans and H.C. Rowe et al., 2018. Genetics of alternative splicing evolution during sunflower domestication. Proc. Natl. Acad. Sci. USA, 115: 6768-6773. DOI: $10.1073 /$ pnas.1803361115

Sossey-Alaoui, K., H. Serieys, M. Tersac, P. Lambert and E. Schilling et al., 1998. Evidence for several genomes in Helianthus. Theor. Applied Genet., 97: 422-430. DOI: 10.1007/s001220050912

Sossey-Alaoui, K., H. Serieys, M. Tersac, P. Lambert and E. Schilling et al., 1999. Molecular relationships of Helianthus based on RAPD markers. Helia, 22: 1-18.

Spring, O. and E.E. Schilling, 1990. The sesquiterpene lactone chemistry of Helianthus sect. Atrorubentes (Asteraceae: Heliantheae). Biochem. Syst. Ecol., 18: 139-143. DOI: 10.1016/0305-1978(90)90048-K

Spring, O. and E.E. Schilling, 1989. Chemosystematic investigation of the annual species of Helianthus (Asteraceae). Biochem. Syst. Ecol., 17: 519-528.

Suresha, P.G., V. Kulkarni Vikas, S.M. Supriya, S. Darshan and B. Patil Chandrashekar, 2017. Genetic diversity analysis in sunflower (Helianthus annuus L.) parental Lines Using SSR and RAPD Markers. Int. J. Curr. Microbiol. Applied Sci., 6: 2069-2076. DOI: 10.20546/ijcmas.2017.607.244
Timme, R.E., B.B. Simpson and C.R. Linder, 2007. High-resolution phylogeny for Helianthus (Asteraceae) using the 18S-26S ribosomal DNA external transcribed specer. Am. J. Botany, 94: 1837-1852. DOI: 10.3732/ajb.94.11.1837

Uma, M.S., K.L. Girishraj URS and H.O. Umesh, 2018. Microsatellite DNA marker aided diversity analysis in confectionery sunflower (Helianthus annuus L.). Int. J. Agric. Sci. Res., 8: 27-34.

Van de Peer, Y. and R. De Wachter, 1993. TREECON: A software package for the construction and drawing of evolutionary trees. Comput. Applied Biosci., 9: 177-182. DOI: 10.1093/bioinformatics/9.2.177

Vischi, M., F. Arzenton, E. De Paoli, S. Paselli and E. Tomat et al., 2006. Identification of wild species of sunflower by a specific plastid DNA sequence. HELIA, 29: 11-18.

Wang, Y., D. Chen, X. He, J. Shen and M. Xiong et al., 2018. Revealing the complex genetic structure of cultivated amaryllis (Hippeastrum hybridum) using transcriptome-derived microsatellite markers. Sci. Rep., 8: 10645-10645. DOI: $10.1038 / \mathrm{s} 41598-018-28809-9$

Yang, S., Q. Zhong, J. Tian, L. Wang and M. Zhao et al., 2018. Characterization and development of EST-SSR markers to study the genetic diversity and populations analysis of Jerusalem artichoke (Helianthus tuberosus L.). Genes Genom., 40: 1023-1032. DOI: $10.1007 / \mathrm{s} 13258-018-0708-y$ 